\title{
O CURRÍCULO DE UMA ESCOLA DE FORMAÇÃO PEDAGÓGICA E A DIMENSÃO AMBIENTAL: DILEMAS ENTRE TEORIA E PRÁXIS
}

\author{
The curriculum of a pedagogical formation school \\ and the environmental dimension: \\ a dilemma between theory and praxis
}

\author{
Luciene Gonçalves Rosa ${ }^{1}$ \\ Valderi Duarte Leite ${ }^{2}$ \\ Monica Maria Pereira da Silva ${ }^{3}$
}

\begin{abstract}
Resumo: $\mathrm{O}$ artigo trata da análise do currículo de uma Escola de formação Inicial, de nível médio, com relação à dimensão ambiental, considerando a necessidade de inserir a discussão das questões ambientais na formação de educadores como prescrito na Política Nacional de Educação Ambiental, que tem como prioridade gerar reflexão e contribuir para uma melhor compreensão do Ambiente e de suas inter-relações e interdependência. Para esse estudo, foi utilizado a técnica da análise de conteúdos, dentre outras. Os resultados refletem a necessidade de se trabalhar a temática ambiental, com enfoque interdisciplinar e transdisciplinar e de Formação continuada para os profissionais da educação.
\end{abstract}

Palavras-chave: Formação inicial. Currículo. Dimensão ambiental.

\begin{abstract}
The article treats of the analysis of the curriculum of a School of Initial formation, of medium level, regarding the environmental dimension, considering the need to insert the discussion of the environmental subjects in the educators' formation as having prescribed in the National Politics of Environmental Education, that has as priority to generate reflection and to contribute for a best understanding understanding of the environment and of your interrelations and interdependence.. For that study, the technique of the analysis of contents was used, among others. The results reflect the need to work the environmental theme, with focus interdisciplinary and transdisciplinary and of continuous Formation for the professionals of the education.
\end{abstract}

Keywords: Pedagogical formatio. Curriculum. Environmental dimension.

\footnotetext{
${ }^{1}$ Bióloga. Mestre em Desenvolvimento e Meio Ambiente. Programa Regional de Pós-Graduação em Desenvolvimento e Meio Ambiente (PRODEMA), Universidade Federal da Paraíba (UFPB). Campina Grande, PB. <luciene-cg@hotmail.com>

${ }^{2}$ Biólogo. Doutor em Hidráulica e Saneamento. Docente, Departamento de Química, Universidade Estadual Paraíba (UEPB). Campina Grande, PB. <valderiduarte@uol.com.br>

${ }^{3}$ Bióloga. Doutora em Recursos Naturais. Departamento de Biologia, UEPB. Campina Grande, PB.

$<$ monicaea@terra.com.br>

${ }^{1}$ Rua Luiza B. Mota, 950, bloco F, apto. 304

Catolé - Campina Grande, PB

58.104-600

583

Ciência \&̊ Educaşão, v. 14, n. 3, p. 583-99, 2008
} 


\section{Introdução}

A história da educação brasileira é marcada pelo descaso, pela falta de compromisso, como coloca Barros (1996). A educação nunca foi prioridade, nunca houve interesse de oferecer educação de qualidade. Gadotti (1998) amplia essa visão ao enfatizar que a educação no país pautou-se em uma educação dominante ou do colonizador, que se caracterizou como sustentáculo da ideologia do desenvolvimento industrial e econômico, do sistema capitalista, como também da exclusão de classes sociais, em detrimento de uma minoria de privilegiados detentores do poder.

Os cursos de ensino técnico profissionalizante surgem, nesse momento, com o intuito de resolver o problema da Formação educacional dessa classe menos favorecida e oprimida pelo sistema, alegando a necessidade de que estes tinham de ingressar no campo de trabalho mais rapidamente, ocultando-se a idéia central, ou seja, a formação dessa classe social, sem haver alteração da ordem do modelo de desenvolvimento vigente (GADOTTI, 1998).

Porém, esse mesmo modelo de desenvolvimento, que contribuiu para a sociedade hodierna, que se caracteriza pela rapidez das transformações, informações e a adoção de valores sociais e culturais que são resultantes desta crise ambiental atual, tem gerado um momento de busca de novos paradigmas. Assim, a educação enquanto instrumento de mudanças sociais tende a passar por uma reconstrução, cuja concretização se fundamenta a partir da reflexão sobre o papel da educação e do educador, perante esse quadro caótico no qual se encontra a sociedade contemporânea, demandando que a escola assuma sua identidade social e política no contexto histórico (PETRAGLIA, 1995).

As modificações acarretadas pela Lei de Diretrizes e Bases da Educação Nacional (LDB), de $n^{\circ}$ 9.394/96 (BRASIL, 1996), trouxeram uma nova roupagem para os cursos profissionalizantes, atualmente de nível médio, inclusive para os cursos de formação de professores na modalidade normal. Essas modificações propuseram a superação total do entendimento tradicional da educação profissionalizante como simples instrumento de uma política de cunho assistencialista, ou, mesmo, como linear ajustamento às demandas do mercado de trabalho (CORDÃO, 2002). Essa sublimação do tradicionalismo exige atualizações, sobretudo na reorganização curricular, ponderada como o bojo da questão educacional, ao considerarmos currículo em sua complexidade, como um elemento fundamental na estrutura da educação, por estar, não só, de acordo com as tendências pedagógicas, mas, de certa forma, envolver, explícita ou implicitamente, a percepção de cada sociedade.

Como afirmam Moreira e Silva (1994), o currículo é um artefato social e cultural, não apenas um elemento inocente e neutro de transmissão desinteressada do conhecimento social. O currículo está implicado em relações de poder, transmite visões sociais particulares e interessadas, produz identidades individuais e sociais particulares; não é um elemento transcendente e atemporal - ele tem uma história, vinculada a formas específicas e contingentes de organização da sociedade e da educação.

Para se adequar a estas novas exigências, foram lançadas as Diretrizes Curriculares Nacionais (DCN) para a formação de professores na modalidade normal em nível médio, cuja proposta solidifica a compreensão de um Ensino enquanto uma "atividade complexa que supõe uma reflexão sistemática sobre a prática, requerendo-se, para tanto, a constituição de conhecimentos, valores e competências estimuladores de uma ação autônoma e, ao mes- 
mo tempo, colaborativa, em face da responsabilidade coletiva, com os procedimentos que deverão assegurar o direito dos alunos aprenderem" (BRASIL, 1999a, p. 15).

A concretização das DCN para a formação de professores na modalidade normal em nível médio requer um currículo que possibilite a aquisição da identidade da escola e a valorização dos educadores e educadoras, além de uma abordagem metodológica que favoreça a instauração de um diálogo crítico e reflexivo, que possibilite, aos educandos e educandas, a construção e reconstrução dos conhecimentos de forma interdisciplinar e contextualizada, que, conforme Petraglia (2001), é a base para a edificação do pensamento complexo, que absorve a compreensão do todo, considerando a inter-relação e interdependência de seus elementos constituintes.

Considerando a idéia da Teoria da Complexidade, de Edgar Morin (PETRAGLIA, 1995), como essência para a síntese de novas competências, salientamos a importância da Educação Ambiental, enquanto dimensão da educação, que constitui ferramenta indispensável à aquisição de novos valores, e de uma nova percepção de mundo, pautada na reflexão da questão ambiental e na conexão dos conhecimentos, contribuindo para a aquisição de competências que tornem os cidadãos mais críticos e ativos, conseqüentemente, capazes de encontrar novas diretrizes norteadoras a uma sociedade mais ecologicamente viável, e promover uma melhor qualidade de vida. Entretanto, a realização da Educação Ambiental converge rumo a um grande desafio que deverá ser enfrentado pela escola: a adequação de novas tendências pedagógicas e, conseqüentemente, do currículo. A práxis pedagógica demonstra que ainda há uma hegemonia no tipo tradicionalista, cujo pragmatismo, característico de seu processo de memorização dos conteúdos, não permite a contextualização, nem há incentivo a novas descobertas, transformando a educação em um mero ato de depositar, no qual os educandos e educandas são depositários e, o/a educador/a, o/a depositante, como afirma Freire (1987), impossibilitando a reflexão, geradora de transformação. Por conseguinte, há necessidade da implantação de metodologias inovadoras e abrangentes, que possibilitem a inserção da Educação Ambiental de forma a contemplar o currículo das escolas de Formação pedagógica, como está estabelecida pela Política Nacional de Educação Ambiental, Lei 9.795/99, em seu artigo $11^{\circ}$, quando afirma que a dimensão ambiental deve constar nos currículos de formação dos professores, em todos os níveis e todas as disciplinas (BRASIL, 1999b).

Além da necessidade de dar subsídios para que os educandos e educandas desenvolvam novos conhecimentos, valores e competências, de forma a abranger o enfoque, também, da dimensão ambiental, presente no currículo de forma articulada e interdisciplinar, as Escolas de Formação Inicial devem se adequar ao novo quadro do Ensino Fundamental, cuja proposta está pautada nos Parâmetros Curriculares Nacionais-PCNs, que objetivam estimular os indivíduos a enfrentar o mundo atual como cidadãos participativos, críticos e profundos conhecedores de seus direitos e deveres (BRASIL, 1997).

Diante desse horizonte que se amplia aos cursos de formação inicial, pretendemos, neste trabalho, realizar uma análise do currículo de uma escola pública de formação inicial, de nível médio, do interior da Paraíba, com relação à dimensão ambiental. 


\section{O currículo no âmbito da pesquisa}

O currículo sempre existiu, mesmo antes de se tornar um campo de pesquisa. A origem da palavra currículo, do latim, curriculum, significa: percurso, carreira, correr, ato de correr (PILETTI, 1991), aponta para variação de tempo. Esta depende das visões de ser humano e da sociedade em questão. Por isso, é conveniente que façamos uma breve reflexão sobre as teorias curriculares que pautaram a educação no decorrer do tempo, ressaltando que estas influenciaram e foram influenciadas pelo modelo de sociedade em questão.

Podemos destacar, de início, o currículo com enfoque tradicional/humanista, o qual se caracterizava enquanto classista e dicotômico, organizado entre disciplinas de caráter manual para os pobres e de caráter humanista para os ricos; baseado na rigidez da visão de mundo teocêntrica e da pedagogia como algo acabado e imutável (CAMPINA GRANDE, 2001). Essa visão de currículo teve início na Grécia, e sofreu mudanças apenas quando a percepção do ser humano e da sociedade, conseqüentemente da pedagogia, adquiriu novos valores, ligados ao modernismo, incorporando ao currículo um caráter moderno/positivista.

Foi somente no final do século XIX e no início deste, que alguns educadores, nos Estados Unidos, começaram a tratar mais sistematicamente de problemas e questões curriculares, onde podemos destacar duas tendências:tecnocrática e progressista (SILVA, 1999). Os modelos tecnocráticos foram defendidos por Bobbitt e Tyler, que percebiam a educação apenas como finalidade de formar os indivíduos para cumprir as exigências profissionais da vida adulta. O currículo se resumia apenas em técnica. Estes dois modelos se diferenciavam um pouco, porque o de Bobbitt estava claramente voltado para a economia, enquanto o de Tyler sustentava as idéias de organização e desenvolvimento do currículo. Já os modelos mais progressistas, como descrito por Dewey, distanciavam-se dos tecnocráticos, pois em seu discurso já colocavam a preocupação com a democracia, ao invés de apenas economia (SILVA, 1999).

As divergências das posições desses pesquisadores, seus modelos de currículos, apresentaram-se como uma reação ao currículo clássico, humanista, provindo da Antiguidade Clássica, da educação da Idade Média e do Renascimento (SILVA, 1999); e adequaram-se muito bem à sociedade capitalista, porquanto não se preocuparam em questionar o papel da escola nessa sociedade, tornando-se um vinculador da ideologia apregoada por essa sociedade. Esses dois modelos estavam, até bem pouco tempo, nos currículos do ensino profissionalizante e, conseqüentemente, do Ensino Médio, respectivamente; mas, por estarem ligados ao paradigma da sociedade capitalista, sendo também agente de exclusão social, foram alvo de inúmeras críticas, construídas a partir de vários movimentos sociais, contra a opressão, que ousaram questionar o papel da escola e do currículo na reprodução dessa sociedade opressora.

Tais movimentos sociais, que criticavam o currículo de reprodução, passaram a buscar apoio nas teorias sociais que estavam sendo desenvolvidas, sobretudo na Europa. Assim, emerge a teoria crítica do currículo, juntamente com a nova sociologia da educação, que contraria os modelos mais tecnocráticos, tradicionalistas. Preocupavam-se em reconhecer a constituição social e histórica do currículo.

O pensamento da teoria crítica do currículo está reputado em três características que, de acordo com Moreira e Silva (1994), são inseparáveis: a ideologia, a cultura e o poder. A ideologia, por ser responsável por organizar e exibir as relações sociais, as quais estão incutidas 
na cultura da sociedade. Por essa íntima relação da ideologia com a cultura é que não podemos separá-las, nem tampouco das relações de poder, já que sempre haverá uma tendência para excluir algo ou alguma classe em favor de outra. A teoria crítica percebe o currículo como campo de produção, de significações e sentidos. Torna-se, assim, um terreno central dessa luta de transformação das relações de poder, ou seja, a existência dessa tríplice relação induz a um currículo onde, ao mesmo tempo em que produz cultura, também se deve questioná-la, indagar qual o conhecimento que está sendo favorecido e por que esse conhecimento, e não outro; se este conhecimento está de alguma maneira a favorecer uma classe social em detrimento de outra classe.

Após a teoria crítica, surge a teoria pós-crítica, que reforça o pensamento da última e abrange, com mais veemência, as idéias das conexões entre saber, gênero, identidade e poder.

Nesse contexto de mudanças curriculares, a Unesco propõe, no relatório Internacional sobre Educação do século XXI, que a educação básica deve desenvolver quatro necessidades básicas para o novo milênio: aprender a conhecer, aprender a aprender, aprender a ser, e aprender a viver. Em cumprimento dessas reivindicações, foram lançadas pela LDB, em 1998, as Diretrizes Curriculares Nacionais do Ensino Médio (DCNEM) (BRASIL, 1998) que têm, como grande desafio do Ensino Médio, agregar e ampliar os conhecimentos do Ensino Fundamental e fomentar competências de caráter geral e profissional, de maneira que contribuam para a constituição de pessoas mais aptas a mudanças, mais autônomas em suas escolhas, mais solidárias, que acolham e respeitem as diferenças, pratiquem a solidariedade e superem a segmentação social. Para isso, traz a sua base curricular dividida em três áreas de conhecimentos: Linguagens e Códigos e suas Tecnologias, Ciências Naturais, Matemática e suas Tecnologias, e Ciências Humanas e suas Tecnologias; enfatizando, nesse contexto, a interdisciplinaridade entre as diversas áreas e, sobretudo, a contextualização entre todos os conhecimentos. Os cursos de formação de professores, enquanto modalidade do Ensino Médio, estão envolvidos nos mesmos princípios determinados pelas DCNEM.

\section{Estrutura curricular da escola pesquisada}

A escola pesquisada atua na formação inicial de nível médio. O interesse pelo curso concentra-se no sexo feminino, em virtude de tratar-se de uma questão cultural antiga, ou seja, o pedagógico se destinava a formar educandas para o exercício do magistério, já que, para as mulheres, restava apenas a opção de trabalho como professora.

A escola funciona desde 1962, com o curso estruturado em uma grade curricular de três séries, equivalente a três anos consecutivos. Mas, no ano de 2000, atendendo ao que institui a Resolução da Comissão de Educação Básica (CEB) n. 2, de 19/04/1999, iniciou suas atividades de reorganização curricular, mudando sua matriz curricular para o Ensino Médio na modalidade normal, dividida nas três áreas: Linguagens e Códigos e suas Tecnologias, Ciências Naturais, Matemática e suas Tecnologias, e Ciências Humanas e suas Tecnologias. Compreende os componentes curriculares: Língua Portuguesa, Língua Estrangeira, Artes, Educação Física, Matemática, Física, Química, Biologia, Geografia e História, apresentando carga horária de quatro anos e formando docentes para a primeira fase do Ensino Fundamental, Educação de Jovens e Adultos e Educação dos Portadores de Necessidades Especiais. 


\section{Metodologia}

\section{Caracterização da pesquisa}

A preocupação em conhecer sua história e realidade sempre existiu nos seres humanos. Com a evolução da ciência, tal necessidade foi tornando-se possível, embora saibamos que a cientificidade seguiu por caminhos do racionalismo, e mesmo com o passar do tempo, quando surgem as ciências sociais, ainda se discute a sua plausividade como conhecimento científico.

A questão de se trabalhar com o próprio ser humano, enquanto sujeito-objeto de pesquisa, realmente tem causado muitas polêmicas. Mas as próprias ciências naturais, por meio da física quântica e da teoria da relatividade, vêm modificando, quebrando esse impasse da aceitação das Ciências Sociais, e demonstrando que a cientificidade não deve ser considerada sinônimo de modelos e normas a serem seguidos, mas deve ser pensada como algo de alta abstração (MINAYO, 2002).

Uma das peculiaridades é saber que Ciências Sociais é historicidade, até porque é fato comprovado a relação intrínseca e extrinsecamente ideológica, que muda com as visões de ser humano e de sociedade. Outro aspecto é a interdependência entre sujeito e objeto. Há uma cumplicidade entre investigados e investigador. Por fim, é necessário saber que o objeto das Ciências Sociais é essencialmente qualitativo.

A pesquisa qualitativa tem como meta trabalhar com dados relativos à realidade que não podem ser quantificados, tipo: valores, aspirações, atitudes, dentre outros. Dentre as diversas técnicas utilizadas na pesquisa qualitativa, destacamos a Análise de Conteúdo, que pode ser considerada como "um conjunto de instrumentos metodológicos cada dia mais aperfeiçoados que se aplicam a discursos diversos" (RICHARDSON, 1999, p. 223).

A técnica da análise de conteúdos tem várias aplicações. Conforme Richardson (1999), toda comunicação que implica a transferência de significados de um emissor a um receptor pode ser objeto de análise de conteúdo. Mas, geralmente, são utilizadas com duas finalidades: para encontrar respostas para as questões formuladas estabelecidas antes do trabalho de investigação (hipóteses); e para descobrir o que está implícito nos conteúdos manifestos (MINAYO 2002).

Para fazermos a análise do currículo da escola pesquisada, quanto à dimensão ambiental, utilizamos a técnica da análise de conteúdo, uma vez que essa análise do currículo perpassa o que está expresso. Por isso, a investigação requer prudência.

\section{$1^{\circ}$ momento:}

No primeiro momento, procuramos investigar o discurso exarado no currículo, destacando os pontos cruciais, isto é, identificando os fragmentos textuais da grade curricular, que pudessem nos levar a compreensão da noção de currículo da Escola.

\section{$2^{\circ}$ momento:}

Após a análise do currículo, delineamos e avaliamos as disciplinas que contêm abordagem referente à dimensão ambiental: Biologia, Química e Geografia. Estas são abordadas nos primeiros três anos da modalidade normal, sendo ministradas duas aulas semanais, distri- 
buídas num quadro de seis educadores/as. Após delinearmos as disciplinas que continham a abordagem da dimensão ambiental em seu conteúdo, traçamos duas estratégias. Primeiro, a observação direta. Nesta, fomos assistir a algumas aulas das disciplinas que apresentavam o enfoque ambiental; em seguida, aplicamos uma entrevista semi-estruturada com os/as educadores/as das referidas disciplinas, procurando indagar sobre diversos pontos: como percebiam a missão da escola; se o currículo estava correspondendo a esse papel da escola; em caso negativo, quais os motivos e quais os desafios que necessitavam ser vencidos para que o currículo pudesse revigorar. Mediante a missão da escola e do currículo, questionamos em que tendência acreditavam mais se englobar. Em seguida, se trabalhavam a dimensão ambiental, quais contribuições realizavam para implantar essa temática no currículo e, se pretendiam contribuir; quais estratégias estavam utilizando ou pretendiam utilizar. Por fim, questionamos se a educação ambiental poderia provocar mudanças e pedimos para que dedicassem uma mensagem para os/as futuros/as educadores/as.

\section{Resultados e discussão}

\section{O currículo e a dimensão ambiental}

O estudo das três áreas de conhecimentos: Linguagens e Códigos e suas Tecnologias, Ciências Naturais, Matemática e suas Tecnologias, e Ciências Humanas e suas Tecnologias, que compõem o currículo da Escola pesquisada, juntamente com a parte diversificada do curso, deixou claro que a dimensão ambiental não foi devidamente contemplada em seu discurso, estando presente de forma fragmentada em apenas três disciplinas: Química, Biologia e Geografia, que correspondem às áreas das Ciências Naturais, Matemática e suas Tecnologias e das Ciências Humanas e suas Tecnologias. Essa quase total ausência da dimensão ambiental contradiz totalmente os princípios das DCNEM, pois, como podem impulsionar o ensino para a construção da cidadania, conseqüentemente, de uma nova sociedade solidária, baseada na eqüidade política, sem referência aos sérios problemas ambientais ${ }^{2}$ que afetam a qualidade de vida de toda a sociedade contemporânea?

Essa situação ainda é mais agravante por estarmos nos referindo não apenas a uma Escola de Ensino Médio e/ou Ensino Médio Profissionalizante, mas a uma unidade escolar de formação docente, ou seja, de futuros/as educadores/as. Tal aspecto nos reporta à sua própria legislação, as DCN para a formação de professores na modalidade normal em nível médio (BRASIL, 1999a), abalizadas na LDB, nas DCNEM e nas referências para formação de professores da modalidade normal em nível médio. Estas apontam novos rumos norteadores à preparação da docência em nível médio, na qual não se aceita mais a formação de um profissional por meio do método reducionista em que conteúdos eram apenas transmitidos e

${ }^{2}$ Como tratamos do Ambiente de uma forma global, quando nos referimos aos problemas ambientais, incluímos conseqüentemente todos os aspectos, sejam naturais, culturais, sociais, políticos ou econômicos. 
estabelecidos nos limites da abordagem tecnocrática, que se destinavam somente ao que fazer e ao como fazer. Defende-se uma metodologia inovadora, na qual as atividades docentes estejam conectadas diretamente à produção de conhecimentos e de aprendizagem, de forma que favoreçam leituras e mudanças da realidade (BRASIL, 1999a); em que os/as futuros/as educadores e educadoras possam aprender a aprender e aprender a ensinar, e, como afirmou Freire (1999), assumirem-se enquanto sujeitos do saber.

O currículo da escola pesquisada no tocante à dimensão ambiental mostra-nos que a realidade ainda não está compatível com essa proposta, pois os educandos e educandas não poderão construir e reconstruir conhecimentos por meio de abordagens com temáticas sobre a situação socioeconômica, a diversidade cultural, étnica, religiosa e de gênero - como está nas referências para formação de professores - sem correlacioná-los ao ambiente; até porque todos estes temas fazem parte do ambiente, e um dos objetivos da Educação Ambiental é desenvolver a compreensão das múltiplas e complexas relações existentes referentes ao Ambiente, demonstrando que envolve aspectos ecológicos, econômicos, sociais, psicológicos, legais, políticos, culturais, científicos e éticos, como estão prescritos na Política Nacional de Educação Ambiental (BRASIL, 1999b).

O discurso curricular da escola apresenta uma preocupação com a contextualização e a interdisciplinaridade. Apesar de este fato ser bastante positivo, por considerarmos estes dois aspectos como elementos inseparáveis e primordiais para a efetivação de uma educação transformadora, também ficou nítido que, na prática, não está funcionando, pois à medida que entendemos a interdisciplinaridade como um processo de construção do conhecimento, capaz de superar a visão disciplinar, elaborando uma nova interpretação da realidade (GUIMARÃES, 2000), percebemos que esse diálogo existente entre os conhecimentos das diversas áreas é bem mais complexo do que, a priori, poderíamos conceituar. Ao que nos parece, a finalidade da interdisciplinaridade possibilitará a implantação da teoria da complexidade, defendida por Morin, cuja característica é a noção da congregação de elementos que são membros e partícipes do todo. Assim, este não se reduz a uma mera soma dos elementos que constituem as partes, (PETRAGLIA, 1995), ou do pensamento sistêmico, que traz uma nova maneira de pensar, a partir da idéia de integração dos fatos, pois as partes não são suficientes para se entender o todo. A Natureza não apresenta blocos de construção isolados, mas, em vez disso, aparece como uma complexa teia de relações entre as várias partes de um todo unificado (CAPRA, 1996) onde o ser humano é apenas mais um elemento dessa teia. Juntos com outros fatores, compõem o Ambiente. Além disso, a contextualização permite aos educandos e educandas que se sintam como sujeitos no processo ensino-aprendizagem, de maneira a possibilitar a construção da identidade de seres sociais e históricos do mundo, e, como tais, saibam ser possível mudar o mundo, a percepção deste, embora as dificuldades existentes possam parecer maiores e intransponíveis. Ao se sentirem protagonistas de sua própria história, acreditam que os obstáculos não se eternizam (FREIRE, 1999) e as mudanças sempre acontecem. 
O currículo de uma escola de formação...

Quadro 1. Fragmentos textuais das disciplinas: Física e Matemática.

\begin{tabular}{|l|l|}
\hline Disciplinas: Matemática e Física & \multicolumn{1}{c|}{ Fragmentos textuais } \\
\hline Contextualização & "Mostrar ao aluno a importância da física na vida cotidiana"; \\
\hline Educar para a vida & $\begin{array}{l}\text { "Estimular o aluno a pensar, a trabalhar a processar as informações } \\
{[\ldots], \text { conscientizá-lo de que a matemática é vida". }}\end{array}$ \\
\hline Desenvolver acriticidade & $\begin{array}{l}\text { "Desenvolver o espírito crítico do aluno, priorizando o que realmente é } \\
\text { importante para o seu dia-a-dia, como também levá-lo à descoberta } \\
\text { dos fatos mais significativos, interligando com outras disciplinas". }\end{array}$ \\
\hline
\end{tabular}

Fonte: Grade curricular fornecida pela escola pesquisada.

Para que essas mudanças ocorram, é necessário que a proposta pedagógica e, conseqüentemente, o currículo da escola, conduza uma práxis educativa que contemple a realidade em todos os aspectos - fato que ainda não acontece na escola pesquisada e, vale ressaltar, na maioria das nossas escolas. Porque os educandos e educandas não podem arquitetar seus conhecimentos de forma integral, se ocorre fragmentação dos mesmos, a exemplo da dimensão ambiental, abordada nas disciplinas de Biologia, de Química e de Geografia, as quais trazem, em seus discursos, a relevância de se tratar da questão ambiental; enquanto disciplinas como Matemática e Física - apesar de enfatizarem a contextualização, a interdisciplinaridade, a necessidade de se desenvolver a criticidade e do educar para a vida, como demonstram os fragmentos textuais apresentados no Quadro 1 - não enfatizam a dimensão ambiental, como se o ambiente estivesse à parte no todo.

Dentre os fragmentos textuais, um dos pontos que merece ser citado é o 'desenvolvimento do espírito crítico' dos educandos e educandas, tendo em vista que a criticidade pode ser considerada vital para a construção e reconstrução dos conhecimentos, sendo fundamental numa educação que aspira à formação, não apenas de profissionais, de educadores e educadoras competentes e comprometidos, mas de seres humanos afetuosos e plenos, que se apresentem como sujeitos de sua história.

\section{O currículo e a práxis dos educadores e educadoras da escola pesquisada}

Tanto os PCNs do Ensino Fundamental quanto do Ensino Médio trazem a relevância de se trabalhar as Ciências Naturais de forma integrada e contextualizada. Os PCNs para o Ensino Fundamental apontam, como objetivo das Ciências Naturais, o desenvolvimento de posturas e valores pertinentes às relações entre os seres humanos, o conhecimento e o ambiente, ressaltando que estes valores estão ligados aos aspectos da vida social, como a cultura e o sistema produtivo, às relações entre o ser humano e a natureza. Cabe, ainda, aos educadores e educadoras, selecionar, organizar e problematizar conteúdos de modo a promover esse avanço no desenvolvimento intelectual dos/as educandos e educandas, contribuindo na construção destes enquanto seres sociais (BRASIL, 1997). Já os PCNs para o Ensino Médio colocam que os conteúdos do Ensino Fundamental devem ser aprofundados, seguindo pensamentos 
mais abstratos e científicos e, tendo como finalidade, a aprendizagem de concepções científicas atualizadas do mundo físico e natural. Vale ressaltar o desenvolvimento de estratégias de trabalho centradas na solução de problemas, no intuito de aproximar o educando do trabalho de investigação científica e tecnológica, como atividades institucionalizadas de produção de conhecimentos, bens e serviços (BRASIL, 2002).

Cientes de que a escola de formação inicial de professores de nível médio deve se adequar a estes dois contextos - ao do Ensino Médio, por fazer parte da Educação Básica, mas também ao Ensino Fundamental, por ter como meta o desenvolvimento de profissionais para esta modalidade - acreditamos ser conveniente destacar as disciplinas Biologia, Química e Geografia, correspondentes às áreas das Ciências Naturais, Matemática e suas Tecnologias, e das Ciências Humanas e suas Tecnologias, respectivamente, as quais enfatizam a dimensão ambiental, para entendermos melhor como está sendo trabalhada, e verificarmos se a prática condiz com o que expressa o currículo.

\section{A dimensão ambiental e a disciplina Biologia}

Segundo os PCNs do Ensino Médio (BRASIL, 2002), o aprendizado de Biologia deve permitir a compreensão da natureza viva e dos limites dos diferentes sistemas explicativos; a contraposição entre os mesmos, e a compreensão de que a ciência não possui respostas definitivas para tudo, tendo como características as possibilidades de ser questionada e de transformar. Deve, ainda, permitir a compreensão de que os modelos na ciência servem para explicar aquilo que podemos inferir; que tais modelos são produtos da mente humana, não a própria natureza. São construções mentais que procuram manter a realidade observada como critério de legitimação.

A disciplina de Biologia, enquanto componente da estrutura curricular da Escola pesquisada, é considerada como de grande relevância para que os educandos e educandas possam reconhecer "o equilíbrio dinâmico da vida com as primeiras interações entre seres vivos e os demais elementos do meio ambiente", como demonstra o Quadro 2, relativo à organização curricular da disciplina de Biologia.

Para que a disciplina Biologia seja ministrada numa perspectiva progressista, configurando-se em uma pedagogia pautada no pensamento ecossistêmico, é necessário que enfatize a interdisciplinaridade e a contextualização dos conhecimentos em uma nova ótica da integração da vida enquanto unidade.

Contudo, de acordo com a entrevista semi-estruturada realizada com o educador e a educadora, responsáveis pela disciplina, a teoria da Biologia não está condizente com a práxis. Com base no exposto, tanto do educador como da educadora, a abordagem da disciplina de Biologia está pautada mais na transmissão do programa de conteúdos presentes na lista do vestibular, do que propriamente na formação dos educandos e educandas enquanto futuros educadores e educadoras. Esta é uma realidade, não nessa escola, como ressalva o trabalho de Paulo (2002). 
O currículo de uma escola de formação...

Quadro 2. Organização curricular da disciplina de Biologia.

\begin{tabular}{|c|c|c|}
\hline \multicolumn{3}{|c|}{ Departamento das Ciências Naturais, Matemática e suas tecnologias } \\
\hline BIOLOGIA & EMENTA & OBJETIVOS \\
\hline $\begin{array}{c}1^{\circ} \text { Ano } \\
\text { modalidade normal }\end{array}$ & $\begin{array}{l}\text { Características gerais dos seres vivos; o } \\
\text { mundo vivo (a célula do organismo) as } \\
\text { primeiras células; componentes inorgânicos } \\
\text { e orgânicos da célula; envoltórios celulares; } \\
\text { citoplasma e suas estruturas; núcleo celular; } \\
\text { fecundação e suas etapas e histologia } \\
\text { animal. }\end{array}$ & $\begin{array}{l}\text { Desenvolver, por meio do estudo } \\
\text { de Biologia, o equilíbrio dinâmico da } \\
\text { vida, com as primeiras interações } \\
\text { entre seres vivos e os demais } \\
\text { elementos do meio ambiente. }\end{array}$ \\
\hline $\begin{array}{c}2^{\circ} \text { Ano } \\
\text { modalidade normal }\end{array}$ & $\begin{array}{l}\text { Sistema de classificação dos seres vivos, } \\
\text { vírus, reino monera, reino protista, reino } \\
\text { fungi, reino plantae, reino animália, fisiologia } \\
\text { vegetal. }\end{array}$ & $\begin{array}{l}\text { Propiciar um aprendizado útil à vida } \\
\text { e ao trabalho, no qual as } \\
\text { informações e os conhecimentos } \\
\text { transmitidos se transformem em } \\
\text { interpretação, julgamento, mudança } \\
\text { e previsão da realidade. }\end{array}$ \\
\hline $\begin{array}{c}3^{\circ} \text { Ano } \\
\text { modalidade normal }\end{array}$ & $\begin{array}{l}\text { Anatomia e fisiologia humana, sistema } \\
\text { nervoso; órgãos dos sentidos, sistema } \\
\text { circulatório e respiratório, sistema digestivo, } \\
\text { sistema excretor. A natureza química e a } \\
\text { função do gene, a transmissão dos genes, } \\
\text { genética de população, ecologia, sucessão } \\
\text { ecológica, ciclos biogeoquímicos, fluxo de } \\
\text { energia, relações ecológicas, dinâmicas das } \\
\text { populações, estudo da biosfera, evolução. }\end{array}$ & $\begin{array}{l}\text { Preparar o educando para a } \\
\text { cidadania no sentido universal, e } \\
\text { não apenas profissionalizante, } \\
\text { aprimorando-o como ser humano } \\
\text { sensível, solidário e consciente. }\end{array}$ \\
\hline $\begin{array}{c}4^{\circ} \text { Ano } \\
\text { modalidade normal }\end{array}$ & & \\
\hline
\end{tabular}

Fonte: Grade curricular fornecida pela escola pesquisada.

Para sabermos mais sobre como o educador e a educadora entendiam da formação inicial e a missão da escola nesse contexto, indagamos sobre o papel da escola. Disseram que "apesar de ser para formar educadores", o que eles percebiam era muito desinteresse por parte dos educandos e educandas. E novamente repetiram que faziam o possível para "passar os assuntos do vestibular". Não podemos desaprovar a intenção do programa, dos educadores e educadoras, até porque a escola é de Ensino Médio. Entretanto, diante da amplitude da missão da Escola, indagamos quanto à inexistência da relação desses conteúdos com a práxis desses futuros educadores e educadoras.

Quanto à metodologia utilizada para as aulas de Biologia, os educadores afirmaram que os conteúdos são ministrados com base em uma coletânea de textos, que são xerocados e/ou copiadas do quadro de giz. Demonstram características tipicamente tradicionalistas, que se contrapõem à legislação e às próprias intenções expostas na organização do currículo da referente disciplina, de modo a dificultar a obtenção dos seus objetivos expostos. 
A respeito da dimensão ambiental, percebemos, com base na conversa com o/a educador/a, que a teoria expressa na grade curricular da disciplina apresentada no Quadro 2, não condiz com a prática, porquanto ambos, educador e educadora, afirmaram que, apesar de o programa ser relacionado ao ambiente, "a abordagem dessa temática é feita apenas em seus aspectos ecológicos, através de leitura e comentários de textos".

Dentre os objetivos citados na organização curricular da disciplina de Biologia, é relevante destacarmos a preocupação em não formar apenas profissionais, mas "seres humanos mais sensíveis, solidários e conscientes", conseqüentemente, aptos a lutarem por uma sociedade mais humanizada, demonstrando, assim, a proposta de conexão entre os conhecimentos e a prática docente.

As afirmativas do educador e educadora de Biologia, de fato, mostram que, na prática, a hegemonia ainda é da tendência tradicional: "Sou mais tradicionalista, até gostaria de ser diferente, mas não há recursos."; "Sou de tudo um pouco. No início da minha carreira profissional era Construtivista, mas a práxis me vez desacreditar da educação. Uma andorinba só não faz verão." (Educador, 25 anos de Magistério)

As revelações do educador e da educadora explicitam a falta de motivação. Mediante expressões, questionamos: como as educandas e os educandos poderão sentir-se motivados a aprender e a abraçar essa profissão ao verem seus educadores/as tão desmotivados/as e sem esperança? Sem esperança não pode haver educação (FREIRE, 1987). É preciso ter esperança.

Sabemos que a educação no país ainda não é levada a sério, que há falta de recursos didáticos, como foi citado por todos os educadores e educadoras dessa escola; que os educandos e educandas, muitas vezes, não têm recursos financeiros para adquirirem seus próprios materiais didáticos; que educadores e educadoras não são remunerados adequadamente, nem valorizados enquanto profissionais. Contudo, se não acreditarmos em mudanças, e não lutarmos, realmente nada mudará.

Com relação à interdisciplinaridade e contextualização expostas no currículo da escola, o/a educador/educadora concordaram que "não está funcionando", e, mais uma vez, ressaltaram que se esforçam para repassar os conteúdos temáticos do vestibular. É nítida a ausência do fomento do aspecto profissional, e da inteligência emocional, demonstrando que a educação não está sendo abordada de forma íntegra, de maneira a contribuir para a formação de cidadãos.

Ao perguntarmos se acreditavam que a Educação Ambiental traz mudanças e qual a mensagem que gostariam de repassar para os educandos e educandas que estão terminando o curso, os dois concordaram que a Educação Ambiental é capaz de realizar mudanças, porém, com ressalvas, "para ser capaz de mudanças é preciso investimento e formação": "Que possam estudar mais!"; "Que elas tenham persistência!".

Quanto às mensagens citadas pelo educador e educadora, ambos demonstraram realmente o que sentem, diante desse cenário tão conturbado da realidade educacional, entre dúvidas e incertezas, utopia e realidade, onde a teoria não estabelece aliança com a práxis.

\section{A dimensão ambiental e a disciplina de Química}

A disciplina de Química, também componente da área das Ciências Naturais, Matemática e suas Tecnologias, do Ensino Médio, tem como objetivo "possibilitar ao aluno a 
compreensão, tanto dos processos químicos em si quanto da construção de um conhecimento científico em estreita relação com as aplicações tecnológicas e suas implicações ambientais, sociais, políticas e econômicas." (BRASIL, 2002, p. 240).

Com essa disciplina, os resultados não foram muito diferentes da disciplina de Biologia. Por meio de observações, percebemos que a metodologia utilizada tem características peculiares de tendência tradicionalista, abalizada em aulas expositivas, com materiais didáticos, textos mimeografados e lousa de giz.

Apregoando a mesma linha de pensamento de Biologia, a disciplina de Química enfatiza, com mais veemência, a construção da criticidade dos educandos e educandas, a qual, com toda certeza, é ponto fundamental para se alcançar o patamar que o discurso curricular aspira: a interdisciplinaridade, contextualização dos conhecimentos para se concretizar a educação transformadora, voltada para a cidadania. O Quadro 3 apresenta a ementa e seus objetivos da disciplina de Química.

Em entrevista semi-estruturada com o/a educador/a da respectiva disciplina, estes expressaram que a interdisciplinaridade e a contextualização exposta no currículo ainda não estão ocorrendo, como corroboram as expressões:

"Como podemos contextualizar se a Escola não dispõe nem ao menos de um laboratório, o que podemos fazer, quando dar é pedir para que lembrem de alguma atividade que já tenham feito em casa, mas isso, depende muito do assunto." (Educador)

Quadro 3. Organização curricular da disciplina de Química.

\begin{tabular}{|c|l|l|}
\hline Departamento das Ciências Naturais & \multicolumn{1}{|c|}{ EMENTA } & \multicolumn{1}{c|}{ OBJETIVOS } \\
\hline QUÍMICA & $\begin{array}{l}\text { Princípios elementares da Química; Tabela } \\
\text { Periódica; ligações químicas; funções } \\
\text { inorgânicas; cálculos químicos e unidades. } \\
\text { modalidade normal }\end{array}$ & $\begin{array}{l}\text { Possibilitar os meios, para que o } \\
\text { aluno desenvolva a capacidade de } \\
\text { observações, comparações, } \\
\text { interpretações, cálculos, e chegar } \\
\text { às conclusões necessárias para o } \\
\text { aprimoramento do espírito lógico. }\end{array}$ \\
\hline $\begin{array}{c}2^{\circ} \text { Ano } \\
\text { modalidade normal }\end{array}$ & $\begin{array}{l}\text { Gases; reações químicas; reações de } \\
\text { oxidação-redução; soluções; introdução à } \\
\text { química orgânica. Química: uma abordagem } \\
\text { ambiental. }\end{array}$ & $\begin{array}{l}\text { Estimular, no aluno, a busca do } \\
\text { conhecimento cientifico, permitindo } \\
\text { o exercício da capacidade de } \\
\text { refletir e assimilar. }\end{array}$ \\
\hline $\begin{array}{c}3^{\circ} \text { Ano } \\
\text { modalidade normal }\end{array}$ & $\begin{array}{l}\text { Isometria; reações orgânicas; termoquímica; } \\
\text { cinética química; equilíbrio químico; equilíbrio } \\
\text { lônico; química nuclear. Química: uma } \\
\text { abordagem ambiental. }\end{array}$ & $\begin{array}{l}\text { Desenvolver, no aluno, a } \\
\text { capacidade de refletir e assimilar o } \\
\text { conhecimento científico. }\end{array}$ \\
\hline $\begin{array}{c}4^{\circ} \text { Ano } \\
\text { modalidade normal }\end{array}$ & \multicolumn{1}{c}{} \\
\cline { 2 - 3 }
\end{tabular}

Fonte: Grade curricular fornecida pela escola pesquisada. 
"Como posso dizer que há interdisciplinaridade se as alunas não conseguem fazer as atividades de química porque não sabem resolver a parte matemática, e ainda não há diálogo nem entre estas duas disciplinas que poderiam ajudar mais.” (Educadora)

Ao perguntarmos sobre qual a tendência a que mais se adequavam, ambos se consideraram tradicionalistas. Embora um deles tenha se justificado, afirmando que "também não é nenhum daqueles carrascos", que existe um diálogo entre ele e seus educandos e educandas, "mas não como alguns educadores, ainda mantém a ordem na sala", coloca que, apesar disso, "agora vai precisar mudar, para se ajustar à nova realidade", da escola e da legislação.

É interessante que tais educadores/as da disciplina de Química já estão mais atentos para a missão, pois, ao perguntarmos sobre tal fato, ambos corroboraram que o papel da escola é de formar educadores e educadoras. Também demonstram estarem mais conscientes de que existem muitos obstáculos a serem vencidos para que o currículo possa vir a funcionar, pois a preocupação maior está ainda voltada para o cumprimento do programa do vestibular.

Quanto à dimensão ambiental na disciplina de Química, um educador destacou que só comentava sobre o Ambiente aleatoriamente, quando o assunto permitia. Ele tecia alguns comentários, como, por exemplo, as substâncias químicas presentes nos agrotóxicos. Também enfatizou que, agora, vai precisar abordar essa temática, porque está havendo várias exigências às quais vão ter de se adequar. Com a educadora a situação foi um pouco mais complicada, porque ela assegurou que a temática ambiental era assunto para a disciplina de Ciências e de Biologia. Por várias vezes, reincidimos no assunto. Sempre argumentava que não fazia parte do seu âmbito de estudo e trabalho.

Apesar disso, os educadores de Química mostraram-se confiantes na viabilidade de a Educação Ambiental proporcionar mudanças; salientam, porém, a necessidade de investimento, de formação.

Com relação às mensagens que deixariam para seus educandos e educandas, foram bastante semelhantes às elaboradas pelos da disciplina de Biologia. Sempre incentivavam os futuros educadores e educadoras para terem persistência, acreditarem que iriam vencer. $\mathrm{O}$ educador ainda acrescentou: "Todo ano sai vários profissionais dessa Escola e sabemos que o indice de desempregados é alto, por isso é preciso ter muita persistência, não desistir!" E é claro, fazer o melhor que poder."

\section{A dimensão ambiental e a disciplina de Geografia}

A disciplina de Geografia é considerada, pelos PCNs do Ensino Médio, como de fundamental importância. Sofreu várias mudanças no transcorrer do tempo, que " [...] foram suscitadas pela revolução técnico-científica, pala globalização da economia e pelos problemas ambientais que deram aos conhecimentos de Geografia um novo significado" (BRASIL, 2002, p. 310).

A Geografia foi a única da área das Ciências Humanas e suas Tecnologias a enfatizar, em seu conteúdo programático, a dimensão ambiental, como mostra o Quadro 4. Estando presente apenas nos três primeiros anos do curso, é ministrada por um educador e uma educadora.

A metodologia utilizada nas aulas da respectiva disciplina também se caracteriza por tradicionalista, com aulas expositivas, leitura de textos comentados e lousa. 
O currículo de uma escola de formação...

Quadro 4. Organização curricular da disciplina de Geografia.

\begin{tabular}{|c|c|c|}
\hline \multicolumn{3}{|c|}{ Departamento das Ciências Humanas e suas tecnologias } \\
\hline GEOGRAFIA & EMENTA & OBJETIVOS \\
\hline $\begin{array}{c}1^{\circ} \text { Ano } \\
\text { modalidade normal }\end{array}$ & $\begin{array}{l}\text { A importância dos acontecimentos } \\
\text { geográficos, englobando fatores políticos, } \\
\text { sociais e econômicos do Brasil, } \\
\text { caracterizando os principais elementos } \\
\text { ligados ao meio ambiente. }\end{array}$ & $\begin{array}{l}\text { Estabelecer um objetivo que } \\
\text { traduza uma nova realidade de } \\
\text { conhecimentos de cada região } \\
\text { brasileira. }\end{array}$ \\
\hline $\begin{array}{c}2^{\circ} \text { Ano } \\
\text { modalidade normal }\end{array}$ & $\begin{array}{l}\text { A importância do estudo da população } \\
\text { brasileira, o ritmo de crescimento e as } \\
\text { causas e efeitos da população, verificamos } \\
\text { a estrutura de sexo, da idade e das } \\
\text { atividades econômicas. }\end{array}$ & $\begin{array}{l}\text { Estabelecer os conceitos e } \\
\text { definições sobre os fenômenos } \\
\text { que ocorrem na superfície } \\
\text { terrestre. }\end{array}$ \\
\hline $\begin{array}{c}3^{\circ} \text { Ano } \\
\text { modalidade normal }\end{array}$ & & \\
\hline $\begin{array}{c}4^{\circ} \text { Ano } \\
\text { modalidade normal }\end{array}$ & & \\
\hline
\end{tabular}

Fonte: Grade curricular fornecida pela escola pesquisada.

Mas, apesar disso, na entrevista semi-estruturada, com relação à missão da Escola, a educadora afirmou que acreditava que o currículo estava funcionando, e se baseava nas experiências de trabalho na Escola, porque, segundo ela, “ já houve muitas mudanças no decorrer do tempo", e ainda acrescentou: "De primeiro era cada um por si, hoje a gente já combina as aulas, já tem uma integração maior".

A educadora corroborou que combina a execução do plano de curso, no decorrer das aulas, com o outro educador da disciplina. Trocam materiais didáticos e procuram realizar as atividades de forma semelhante.

Ao indagarmos sobre a dimensão ambiental da disciplina de Geografia, alegaram não haver tido tempo para trabalhá-la. Todavia, asseguraram já estarem combinando entre si, para que, no próximo ano letivo, possam desenvolver essa temática.

Apesar da pretensão do educador e da educadora de planejarem tratar a dimensão ambiental no próximo ano letivo, não podemos deixar de questionar como podem ter enfatizado "os acontecimentos geográficos, englobando fatores políticos, sociais e econômicos do Brasil", como demonstram seus objetivos, apresentados no Quadro 4, sem discutir a dimensão ambiental, haja vista que os problemas ambientais mais sérios são exatamente os que envolvem essas questões.

No tocante à Educação Ambiental, o educador e a educadora colocaram que, se for realizada corretamente, certamente provocará muitas mudanças.

Por fim, às mensagens para seus educandos e educandas reafirmaram o pensamento dos demais, educadores/as entrevistados/as, transmitindo que estes futuros profissionais devem ter muita persistência e acreditarem em seu potencial. 
Rosa, L. G.; Leite, V. D.; Silva, M. M. P.

\section{Considerações finais}

- A dimensão ambiental não está devidamente contemplada no currículo da escola estudada, tornando-se mais um entrave à concretização da Política Nacional de Educação Ambiental, haja vista que, na escola estudada, formam-se profissionais da educação que irão atuar no Ensino Fundamental I, e que não são preparados para inserir a dimensão ambiental na sua prática.

- Os educadores e as educadoras que já contemplam a dimensão ambiental nas disciplinas ministradas, trabalham-na de forma fragmentada, superficial e numa visão apenas ecológica, esquecendo das outras facetas que compõem o Ambiente. Este fato é compreensível, porque, na maioria das universidades brasileiras, a dimensão ambiental não é devidamente contemplada, nem mesmo nos cursos de licenciaturas.

- É urgente a implementação da Política Nacional de Educação Ambiental em todos os níveis de ensino, e que a dimensão ambiental faça parte do currículo da formação inicial de professores das várias áreas do conhecimento; o que pressupõe investimento na formação continuada dos (as) educadores (as) que não tiveram oportunidade de preparação no ensino superior. Porém, ressaltamos que esta formação deve ser implementada de forma continuada. Normalmente, os projetos para este fim são de curta duração e sem o devido acompanhamento.

- A inserção da dimensão ambiental no currículo requer investimento no processo de sensibilização de forma contínua, desde a formação inicial dos educadores e das educadoras, como na formação continuada, a exemplo da escola pesquisada, visando sensibilizá-los sobre a necessidade de reflexão-ação individual e coletiva, e, consecutivamente, na práxis pedagógica.

\section{Referências}

BARroS, M. A educação no Brasil. Jornal O Norte Paraíba, p. 32, 1996.

BRANDÃO, C. R. O que é educação. São Paulo: Brasiliense S/A, 1995. (Coleção Primeiros Passos).

BRASIL. Ministério da Educação. Parâmetros Curriculares Nacionais Ensino Médio. Brasília: MEC/SEMTEC, 2002.

. Ministério da Educação. Diretrizes Curriculares Nacionais para a formação de professores na modalidade normal em nível médio. Brasília: MEC, 1999a.

Política Nacional de Educação Ambiental. Lei n. 9.795, de 27 de abril de 1999. Dispõe sobre a Educação Ambiental, institui a Política Nacional de Educação Ambiental e dá outras providências. Brasília, 1999b.

Diretrizes Curriculares Nacionais para o Ensino Médio. Brasília: MEC, 1998.

Parâmetros Curriculares Nacionais. Brasília: MEC, 1997. 
O currículo de uma escola de formação...

BRASIL. Ministério da Educação e do Desporto. Lei de Diretrizes e Bases da Educação Nacional. Brasília: MEC, 1996.

CAMPINA GRANDE. Política Curricular na Rede Municipal de Campina Grande.

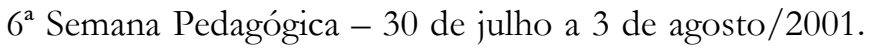

CAPRA, F. A teia da vida: uma nova compreensão científica dos sistemas vivos. São Paulo: Cultrix, 1996.

CORDÃO, F. A. A LDB e nova educação orofissional. Boletim Técnico do SENAC, Rio de Janeiro, v. 28, n. 1. p. 11-23, 2002.

FREIRE, P. Pedagogia da autonomia: saberes necessários à prática educativa. 7. ed. São Paulo: Paz e Terra, 1999.

Pedagogia do oprimido. 17. ed. Rio de Janeiro: Paz e Terra, 1987.

GADOTTI, M. Educação e poder: introdução à pedagogia do conflito. 11. ed. São Paulo: Cortez, 1998.

GUIMARÃES, M. Educação ambiental: no consenso um embate? Campinas: Papirus, 2000.

MINAYO, M. C. S. (Org.). Pesquisa social: teoria, método e criatividade. Petrópolis: Vozes, 2002.

MOREIRA, A. F.; SILVA, T. T. (Orgs.). Currículo, cultura e sociedade. São Paulo: Cortez, 1994. cap. 1.

PAULO, V. F. Na prática a teoria é outra. 2002. Trabalho de Conclusão de Curso (Graduação em Licenciatura e Bacharelado em Ciências Biológicas) - Universidade Estadual da Paraíba, Campina Grande, 2002.

PETRAGLIA, I. C. Edgar Morin: a educação e a complexidade do ser e do saber. Petrópolis: Vozes, 1995.

PILETTI, C. Didática geral. 14. ed. São Paulo: Ática, 1991.

RICHARDSON, R. J. Pesquisa social: métodos e técnica. São Paulo: Atlas, 1999.

SILVA, M. M. P. Estratégias em Educação Ambiental. 2000. Dissertação (Mestrado em Desenvolvimento e Meio Ambiente) - Universidade Federal da Paraíba, João Pessoa, 2000.

SILVA, T. T. Documentos de identidade: uma introdução às teorias do currículo. 2. ed. Belo Horizonte: Autêntica, 1999.

Artigo recebido em dezembro de 2007 e aprovado em maio de 2008. 